\title{
DAMPAK POLUSI PARTIKEL DEBU DAN GAS KENDARAAN BERMOTOR PADA VOLUME DAN KAPASITAS PARU
}

\author{
Jehosua S.V. Sinolungan \\ Bagian Psikologi Fakultas Kedokteran Universitas Sam Ratulangi Manado
}

\begin{abstract}
The increasing number of vehicles which increase air pollution has negative impacts on global health, especially that of lung problems. Nowadays, people's mobility is fast and variable, needing better and more environmentally friendly transportation, without neglecting the socio-economic aspect. These are the reasons to develop better and more environmentally related transportation facilities. By understanding air pollution mechanisms, and kinds of particles and pollutants from vehicles, we will appreciate and pay more attention to our environment, especially in urban areas. Collaboration among health and government related departments has to be improved to regulate the use of inner city vehicles, so that it can decrease lung problems.
\end{abstract}

Keywords: air pollution, transportation, dust particles, urban environment

\begin{abstract}
Abstrak: Bertambahnya jumlah kendaraan bermotor seiring dengan bertambahnya polusi udara, dan menimbulkan masalah global, yang berdampak negatif antara lain masalah kesehatan paru. Mobilitas manusia semakin beragam sehingga diperlukan dukungan sistem transportasi yang makin baik pula serta akrab lingkungan, tanpa mengabaikan segi sosioekonomi. Oleh karena itu sistem transportasi ini perlu dikembangkan menjadi sistem transportasi yang berkelanjutan. Diharapkan dengan mengetahui batasan polusi udara, jenis, serta dampak partikel debu dan gas kendaraan bermotor bagi kesehatan manusia akan membuat kita lebih mencintai dan memperhatikan lingkugan hidup kita, khususnya sekitar perkotaan. Perana kerjasama lintas sektoral untuk mengatasi polusi partikel debu dan gas buangan perlu ditingkatkan Pengaturan kendaraan layak beroperasi akan menekan meningkatnya kasus infeksi atau gangguan saluran napas.
\end{abstract}

Kata kunci: polusi udara, transportasi, partikel debu, lingkungan perkotaan

Sejalan dengan kehidupan masyarakat yang makin maju, jumlah kendaraan bermotor makin bertambah mengakibatkan polusi udara makin bertambah dan menjadi masalah internasional, menimbulkan dampak negatif antara lain masalah kesehatan. ${ }^{1}$

Penyakit paru merupakan salah satu masalah kesehatan utama di Indonesia. Berdasarkan survei kesehatan rumah tangga (SKRT) yang dilaksanakan oleh Departemen Kesehatan Republik Indonesia, dari waktu ke waktu tampak bahwa sekitar 30$40 \%$ penyakit dan penyebab kematian di Indonesia adalah penyakit paru dengan berbagai bentuknya. ${ }^{2}$
Hasil Survey Nasional tahun 1992 menunjukkan bahwa penduduk Jakarta yang menderita gejala batuk dalam satu bulan akibat polusi udara meningkat dari $16,8 \%$ menjadi $22,5 \%$ dan kematian akibat infeksi saluran napas juga meningkat dari 6,2\% pada tahun 1986 menjadi $9,2 \%$ pada tahun $1992 .^{3}$

Mobilitas manusia semakin beragam sehingga dukungan sistem transportasi makin baik. Sistem transportasi yang tidak bersahabat dengan lingkungan akan memberikan dampak langsung maupun tidak langsung bagi kehidupan manusia seperti dampak terhadap lingkungan, kesehatan 
maupun sosial ekonomi. Oleh karena itu untuk menghindari semakin menurunnya kualitas lingkungan maka sistem transportasi ini perlu dikembangkan menjadi sistem transportasi yang berkelanjutan. Sistem transportasi berkelanjutan sangat erat kaitannya dengan jenis kendaraan yang beroperasi, perencanaan tata ruang/tata kota, jenis bahan bakar yang ramah lingkungan, teknologi pembakaran dan pengendalian gas buangan kendaraan bermotor serta pengaturan lalu lintas yang ada. Sistem transportasi yang berkelanjutan ini dapat mendukung mobilitas manusia dalam memenuhi kebutuhan hidup tanpa menyebabkan kerusakan lingkungan sekitarnya. ${ }^{4}$

Masalah pencemaran udara dari sektor transportasi perlu mendapat perhatian serius. Sektor transportasi telah menjadi kontributor utama terjadinya pencemaran udara khususnya di Indonesia. Penggunaan bahan bakar yang tidak ramah lingkungan dari kendaraan bermotor menghasilkan debu dan gas buangan yang merupakan campuran gas-gas serta partikel-partikel yang berbahaya terhadap kesehatan manusia bahkan lingkungan sekitarnya. ${ }^{4}$

Polutan-polutan pencemar udara yang terkandung dalam partikel terdiri atas timah hitam dalam debu, partikel padat $2,5 \mu \mathrm{m}$, partikel padat $10 \mu \mathrm{m}$ dan aerosol; dalam gas buangan kendaraan bermotor terdiri atas karbon monooksida (CO), nitrogen oksida (NOx), hidrokarbon (HC), sulfur oksida (SOx), timah hitam (Plumbum/Pb). ${ }^{5}$ Menurut data Menteri Kependudukan dan Lingkungan Hidup, kendaraan bermotor menyumbang polutan-polutan sebanyak $70 \% \mathrm{CO}, 100 \% \mathrm{~Pb}, 60 \% \mathrm{HC}$ dan $60 \%$ NOx dari seluruh polutan yang mencemari udara atmosfer (Tabel 1). ${ }^{6}$

Menurut prediksi para ahli Kesehatan Lingkungan di Amerika Serikat pada sekitar tahun 2000-an kematian yang disebabkan oleh pencemaran udara akan mencapai 57.000 orang pertahunnya. Selama 20 tahun terakhir ini American Lung Association melaporkan angka kematian yang disebabkan oleh pencemaran udara naik mendekati $14 \%$ atau mendekati $0,7 \%$ pertahun. Penelitian yang dilakukan di Amerika Serikat pada tahun 1980 ditemukan bahwa kematian disebabkan oleh pencemaran udara mencapai angka kurang lebih 51.000 orang per tahun. Angka ini cukup mengerikan karena bersaing keras dengan angka kematian yang disebabkan oleh penyakit lainnya, seperti penyakit jantung koroner, kanker, acquired immuno deficiency syndrom (AIDS) dan lain sebagainya. ${ }^{4}$

Indonesia sebagai salah satu negara di Asia yang berkembang menjadi negara industri baru juga menghadapi masalah polusi udara, dimana yang paling sering oleh asap kendaraan bermotor dan asap pabrik. Tingkat polusi udara terutama di kota-kota besar di Indonesia makin meningkat sehingga masalah kesehatan terutama pernafasan juga bertambah. ${ }^{3}$

Indonesia yang merupakan negara dengan jumlah penduduk terbesar ke lima di dunia belum menerapkan standar euro ini padahal jumlah pertambahan kendaraan bermotor mencapai $10 \%$ pertahun, khususnya dibandingkan dengan Bitung mencapai $31,3 \%$, Manado mencapai $30 \%$ sedangkan Sulut mencapai $4 \%$. Kota-kota besar di Indonesia mengalami pencemaran udara yang tinggi. Hal ini disebabkan karena peningkatan jumlah kendaraan bermotor, yaitu kurang lebih $90 \%$ dari seluruh kendaraan bermotor tersebut masih menggunakan teknologi lama yaitu sistem karburator yang disertai dengan peningkatan penggunaan bahan bakar motor. ${ }^{7}$

Pajanan polusi udara dalam jangka lama, dapat menimbulkan perubahan atau kerusakan histopatologi paru, mengamati kumulatif pajanan dari debu (dust) terhadap penurunan fungsi paru pekerja terowongan jalan raya menemukan mereka rata-rata terpapar debu pada saluran pernapasan antara $1,2-3,6 \mathrm{mg} / \mathrm{m}^{3}$ dan $0,019-0,044 \mathrm{mg} / \mathrm{m}^{3}$ (dalam $\alpha$-quartz) serta terjadi penurunan $\mathrm{FEV}_{1}$ karena pengaruh pajanan debu pada saluran napas dengan hasilnya $\mathrm{p}<0,001$ dan $\alpha-$ quartz $\mathrm{p}=0,02$. Peters, et al. ${ }^{10}$, dalam penelitian mereka melaporkan adanya peningkatan polusi udara oleh partikulat menjadi pencetus terjadinya infark miokardium. ${ }^{8,9}$ Samet et al. dalam penelitian mereka terhadap partikulat baik padat atau cair seperti 
Tabel 1. Beberapa bentuk dan akibat bahan pencemar udara

\begin{tabular}{lcl}
\hline \multicolumn{1}{c}{ Bahan Pencemar } & $\begin{array}{c}\text { Lokasi Pencemaran pada } \\
\text { umumnya }\end{array}$ & $\begin{array}{c}\text { Akibat terutama pada individu / } \\
\text { masyarakat }\end{array}$ \\
\hline Sulfur dioksida $\left(\mathrm{SO}_{2}\right)$ & $\mathrm{Ud} \mathrm{a} \mathrm{r} \mathrm{a}$ & Bronkitis - Alergi - Mutasi sel \\
Karbon monooksida $(\mathrm{CO})$ & $\mathrm{Ud} \mathrm{a} \mathrm{r} \mathrm{a}$ & Gangguan Proses Pernapasan \\
Karbon dioksida $\left(\mathrm{CO}_{2}\right)$ & $\mathrm{Ud} \mathrm{a} \mathrm{r} \mathrm{a}$ & Green - House Effect \\
Nitrogen oksida $\left(\mathrm{NO}_{2}\right)$ & $\mathrm{U} \mathrm{d} \mathrm{a} \mathrm{r} \mathrm{a}$ & Iritasi dan Mutasi sel paru \\
$\mathrm{D} \mathrm{e} \mathrm{b} \mathrm{u}$ & $\mathrm{Ud} \mathrm{a} \mathrm{r} \mathrm{a} \mathrm{-} \mathrm{A} \mathrm{i} \mathrm{r}$ & Bronkitis. \\
\hline
\end{tabular}

debu (dust), serbuk sari bunga (pollen) dan aerosol pada aktifitas pembakaran bahan bakar fosil ditemukan bahwa ukuran partikel yang berperan signifikan di bagian dalam paru-paru dengan terkumpulnya partikel ukuran diameter $<2-3 \mu \mathrm{m}$ yaitu pada bronkiolus terminalis dan alveoli sedangkan partikel berukuran lebih besar akan terkumpul di saluran napas bagian atas. ${ }^{11}$

\section{Bahan penyebab pencemar udara dan a- kibat pada kesehatan}

Amsyari mengemukakan tentang bahan pencemar udara dan beberapa akibat karena pencemaran lingkungan bisa dilihat dalam Tabel $1 .^{12}$

Menurut Harsanto, ${ }^{13}$ sifat dari sumber pencemar udara terbagi tiga jenis yaitu:

1. Sumber titik (Point Source)

Sumber titik adalah sumber pencemar yang berasal dari sumber stasioner, tunggal dan dapat diidentifikasikan keberadaannya. Contoh dari sumber titik adalah emisi gas dari cerobong asap pabrik, cerobong asap pembangkit listrik tenaga diesel.

2. Sumber kawasan (Area Source)

Sumber kawasan adalah sumber pencemar yang berasal dari beberapa titik yang berdekatan atau berasal dari sumber bergerak (mobile source) pada daerah tertentu. Contoh dari sumber kawasan adalah pencemaran udara akibat kepadatan arus lalulintas.

3. Sumber garis (Line Source)

Sumber garis adalah sumber pencemar yang berasal dari emisi berbentuk garis misalnya pencemar udara dan kebisingan pesawat terbang di bandar udara pada saat mendarat atau berangkat.
Di Amerika Serikat, gas CO dilaporkan Kindwall merupakan penyebab tersering keracunan di dunia industri. ${ }^{14}$ Menurut Fine diperkirakan terjadi 3.500-3.800 kematian dari 10.000 kematian akibat keracunan gas CO setiap tahunnya. ${ }^{15}$

\section{Polutan udara dan dampaknya dapat di- uraikan sebagai berikut:}

\section{Debu/partikel di udara}

Debu yang halus, uap air yang secara umum disebut total kelarutan debu atau partikulat (TSP: Total Suspended Particulates) merupakan salah satu bentuk pencemar yang berbahaya. Banyak bentuk senyawaan kimia di udara terikat dalam partikel. Besarnya debu itu sangat mempengaruhi keberadaannya di udara, bertambah kecil diameternya keberadaannya tambah lama atau penyebarannya semakin luas. U.S. EPA ${ }^{16}$ melalui National Ambient Air Quality Standard (NAAQS) memberikan nilai ambang batas untuk PM10 sebanyak $150 \mu \mathrm{gr} / \mathrm{m}^{3}$ sedangkan $\mathrm{WHO}^{17}$ memberikan nilai ambang batas $50 \mu \mathrm{gr} / \mathrm{m}^{3}$.

Bahan-bahan partikel/debu merupakan bahan-bahan kompleks dan campuran yang terdiri dari partikel-partikel dasar karbon (carbon based particles), debu (dust), dan aerosol asam (acid aerosol). Bahan parti$\mathrm{kel} / \mathrm{debu}$ yang terbanyak mengganggu paru yaitu PM2,5 dan PM10. ${ }^{4}$

Mekanisme masuknya partikel secara akut dilaporkan Bruce menyebabkan iritasi bronchial, peningkatan reaktivitas paruparu, menekan pergerakan mukosiliar dan menekan respon makrofag serta imunitas lokal. Selain itu pada keadaan terpapar lama menyebabkan reaksi fibrotik, gangguan keseimbangan autonomik, aktifitas koagulan 
dan stres oksidasi dalam paru-paru. ${ }^{18}$

Menurut Bruce efek potensial terhadap kesehatan menyebabkan sesak napas, asma yang kambuhan (exacerbation), infeksi saluran napas, bronkitis kronis dan chronic obstruction pulmonary disease (COPD), serta COPD yang kambuhan. Pada gangguan autonomik bisa menyebabkan kematian terutama karena penyakit kardiovaskular. $^{18}$

Laporan dari Committee on the Medical Effects of Air Pollutants (COMEAP), tentang perbandingan kualitas udara, bahwa partikel PM 10 dari studi epidemiologi yang luas menyebabkan efek lanjutan pada kesehatan manusia yaitu meningkatnya angka kematian setiap hari, meningkatnya pasien yang di rawat di rumah sakit dengan keluhan gangguan jantung dan paru-paru, dan buruknya seseorang dengan asma. Komite melaporkan di kota Birmingham dengan populasi satu juta orang didapat dalam sehari konsentrasi partikel rata-rata setiap hari antara $25-50 \mu \mathrm{gr} / \mathrm{m}^{3}$ (24 jam rata-rata) terjadi peningkatan pasien yang masuk rumah sakit untuk diobati gangguan pernapasannya. ${ }^{19}$

\section{Kandungan $\mathrm{Pb}$ dalam debu}

Kandungan timah hitam $(\mathrm{Pb})$ dalam debu di udara umumnya merupakan hasil pembakaran bahan bakar minyak yang mengandung Tetra Ethyl Lead (TEL) yang ditambahkan guna meningkatkan nilai oktan bahan bakar minyak. $^{20}$

Dari spesifikasi bahan bakar minyak yang diproduksi di Indonesia, bensin premium mengandung Tetra Ethyl Lead (TEL) maksimal 2,5 ml/gallon atau 0,7 gr Pb/liter. Baku mutu yang diperkenankan untuk kandungan $\mathrm{Pb}$ dalam debu adalah $60 \mu \mathrm{gr} / \mathrm{m}^{3}{ }^{2}{ }^{21}$

Proses biologis pencemaran $\mathrm{Pb}$ di udara dimana komponen $\mathrm{Pb}$ inorganik di alam kebanyakan dalam bentuk partikel padat. Di DKI Jakarta tahun 1999 dilaporkan pada Tabel 2 kadar timbal dalam debu. ${ }^{21}$

Setelah terlepas ke udara, partikel ini akan menyebar dan akhirnya hilang karena berbentuk endapan basah atau endapan kering. Kira-kira 40-70\% endapan $\mathrm{Pb}$ yang bersifat basah jatuh sedangkan 20-60\% par- tikel $\mathrm{Pb}$ yang di buang dari kendaraan bermotor tetap berada dekat dengan lokasi sumber pembuangan. ${ }^{22}$

Tabel 2. Kadar timbal dalam debu di DKI Jakarta tahun 1999

\begin{tabular}{lc}
\hline \multicolumn{1}{c}{ Peruntukan } & Kadar $\mathbf{P b}\left(\boldsymbol{\mu g r} / \mathbf{m}^{\mathbf{3}}\right)$ \\
\hline Pemukiman & $0,016-1,3720$ \\
Industri & $0,082-0,309$ \\
Rekreasi & $0,105-0,242$ \\
Perkantoran & $0,007-0,410$ \\
\hline
\end{tabular}

Faktor terpenting dalam menentukan transpor $\mathrm{Pb}$ di udara yakni besar dari partikel $\mathrm{Pb}$ itu sendiri. Partikel $\mathrm{Pb}$ yang berdiameter lebih dari $2 \mu \mathrm{m}$ dapat jatuh dari udara dengan cepat dan tersimpan relatif dekat dengan sumber pelepasan partikel, dimana jika dilepas dari jalan raya maka partikel itu akan jatuh kurang lebih 25 meter dari jalan raya. Kecepatan penyebaran partikel $\mathrm{Pb}$ yang berukuran antara 0,06-2 $\mu \mathrm{m}$ diperkirakan 0,2-0,5 cm/detik, tapi secara keseluruhan partikel $\mathrm{Pb}$ yang bersifat kering mempunyai kecepatan penyebaran $0,41 \mathrm{~cm} /$ detik. $^{22}$ Partikel $\mathrm{Pb}$ yang dilepaskan dari kendaraan bermotor berukuran sangat kecil yaitu kurang dari $0,1 \mu \mathrm{m}$ tapi dapat mengalami koagulasi dari partikel sehingga ukurannya menjadi lebih besar. ${ }^{23}$

\section{Gas sulfur dioksida di udara}

Sulfur dioksida $\left(\mathrm{SO}_{2}\right)$ merupakan bagian partikel gas yang mencemari udara. Sifat $\mathrm{SO}_{2}$ mudah larut dalam air, tidak berwarna, berbau tajam atau pedas pada konsentrasi sekitar 0,5 sampai $0,8 \mathrm{ppm}$ dan iritan yang kuat. Sulfur dioksida dapat berasal dari pembakaran batubara dan minyak mentah yang mengandung sulfur, pembangkit tenaga listrik bertenaga batubara, pabrik yang menghasilkan bubur kertas, peleburan seng, timah dan tembaga serta pemanas ruangan. ${ }^{1}$

Gambaran kualitas udara di DKI Jakarta didapatkan adanya pengaruh $\mathrm{SO}_{2}$ melebihi batas yang diperbolehkan, ${ }^{21}$ dimana 95\% gas $\mathrm{SO}_{2}$ akan terhirup selama proses pernapasan. ${ }^{1}$

Kadar $\mathrm{SO}_{2}$ yang terpajan pada manusia 
di udara bebas lebih rendah dibandingkan pada pekerja dalam ruangan yang terpolusi atau dalam mobil dengan polusi asap kendaraan. ${ }^{1}$ Batas pajanan jangka pendek untuk pekerja di Amerika Serikat dan beberapa negara sebesar 5 ppm. ${ }^{24}$ Nilai standar $\mathrm{SO}_{2}$ berdasarkan National Primary Air Quality Standards in the United States adalah 0,03 ppm (80 mikro-gram $\left./ \mathrm{m}^{3}\right)$ rata-rata per tahun dan $0,14 \mathrm{ppm}$ (365 mikrogram $/ \mathrm{m}^{3}$ ) rata-rata per hari. ${ }^{1}$ Konsentrasi $\mathrm{SO}_{2}$ di udara ambient tetap dibawah 0,04 ppm, ${ }^{24}$ Metode pengukuran gas $\mathrm{SO}_{2}$ menurut United States Environmental Protection ialah dengan teknik pulsed fluorescent (continuous). ${ }^{16,25}$

Environmental chemistry, air and water pollution melaporkan bahwa gas $\mathrm{SO}_{2}$ pada konsentrasi 8-12 ppm memberi efek iritasi saluran pernapasan, $20 \mathrm{ppm}$ iritasi mata dan batuk, 50-100 ppm maksimum pemaparan 30 menit, dan 400-500 ppm menimbulkan gejala berbahaya pada waktu yang singkat. $^{21}$

Pajanan $\mathrm{SO}_{2}$ pada kadar 1-5 ppm dapat menyebabkan iritasi mata, konsentrasi $\mathrm{SO}_{2}$ antara 5-10 ppm menyebabkan iritasi mata dan mukosa hidung sedangkan pajanan dengan konsentrasi antara 10-50 ppm selama 5 sampai 15 menit dapat menyebabkan iritasi mata, hidung, tenggorok, juga timbul rasa tercekik di leher, nyeri dada, dan bronkokonstriksi. Konsentrasi $\mathrm{SO}_{2}$ lebih dari 50 ppm menimbulkan kerusakan parenkim paru dan vaskularisasi paru yang berat, sehingga terjadi perubahan fungsi dan anatomi paru. ${ }^{26,27}$

US EPA melaporkan bahwa pada proses pembakaran bahan bakar akan menghasilkan $85 \%$ dari seluruh emisi $\mathrm{SO}_{2}$, sedangkan sumber lain berasal dari proses industri dan transportasi. ${ }^{16}$ Diameter polutan gas yang mengandung $\mathrm{SO}_{2}$ berukuran antara 3-30 $\mu \mathrm{m}$ akan tersebar berupa partikel padat halus (fine) yang masuk ke paru-paru lewat inhalasi. $^{28}$

Kadar standar $\mathrm{SO}_{2}$ di Indonesia sebesar 0,1 part per millin (ppm) per 24 jam. ${ }^{3}$ Sulfur dioksida dapat bereaksi dengan berbagai partikel dan dapat membentuk hujan asam. Jumlah total $\mathrm{SO}_{2}$ yang dilepaskan di udara diperkirakan 100x106 ton per tahun. ${ }^{29}$
Akibat pajanan $\mathrm{SO}_{2}$ dapat timbul iritasi konjungtiva, kulit dan saluran napas menyebabkan gangguan fungsi paru baik akut maupun kronik, bahkan kematian. ${ }^{27}$

Pada pernapasan biasa melalui hidung, hampir $98 \%$ gas $\mathrm{SO}_{2}$ akan diabsorbsi di nasofaring dan sisanya akan di absorbsi dengan cepat di mukosa serta epitel di bronkus. Hal ini karena turbulensi udara dengan mukosa hidung pada pernapasan biasa relatif sangat besar sehingga gas-gas yang diabsorbsi meningkat. Hanya sedikit, bahkan hampir tidak ada yang sampai ke saluran napas bawah. Pada pernapasan melalui mulut, gas $\mathrm{SO}_{2}$ yang diabsorbsi lebih sedikit dibandingkan melalui hidung. Namun dalam keadaan khusus misalnya bekerja berat, ventilasi per menitnya akan meningkat, sehingga jumlah udara yang dihisap melalui mulut meningkat dan deposit gas $\mathrm{SO}_{2}$ dapat mengenai saluran napas bawah. ${ }^{26}$

\section{Gas nitrogen oksida di udara}

Udara bersih mengandung kurang lebih $78 \%$ gas nitrogen dan $20 \%$ gas oksigen. Pada temperatur tinggi $\left(121^{\circ} \mathrm{C}\right.$ atau $\left.200^{\circ} \mathrm{F}\right)$ kedua gas akan bereaksi membentuk $\mathrm{NO}_{\mathrm{x}}$ dan $\mathrm{NO}_{2}$. Konsentrasi $\mathrm{NO}_{\mathrm{x}}$ yang terukur di DKI Jakarta selama periode 1999/2000 di daerah pemukiman rata-ratanya antara 0,0100 $0,0286 \mathrm{ppm}$, perkantoran $0,0180 \mathrm{ppm}$, industri antara 0,0130-0,0258 ppm dan daerah rekreasi berkisar antara 0,0294 $\mathrm{ppm}^{21}$

American Lung Association, ${ }^{30}$ mengemukakan bahwa sumber $\mathrm{NO}_{\mathrm{x}}$ berupa gas buangan kendaraan di jalan raya (30\%) dan pembakaran minyak tanah atau alat-alat listrik (28\%). Mekanisme kerja $\mathrm{NO}_{\mathrm{x}}$ dapat menyebabkan timbulnya infeksi saluran pernapasan dan gangguan fungsi paru. ${ }^{31}$

Semakin tinggi konsentrasi $\mathrm{NO}_{2}$ di tempat tinggal anda semakin besar resiko anda yaitu mekanisme masuknya bila secara akut meningkat akan menyebabkan reaktifitas bronkial dan bila jangka panjang meningkatkan menyebabkan paru-paru mudah terinfeksi dengan bakteri dan virus. Adapun efek potensial terhadap kesehatan menyebabkan sesak napas dan asma yang berulang 
(exacerbation), infeksi saluran pernapasan serta menurunkan fungsi paru-paru, terlebih bila pada anak-anak. ${ }^{18}$

\section{Gas karbon monoksida di udara}

Gas karbon monoksida adalah gas yang tidak berbau, ${ }^{32,33}$ tidak berwarna dan tidak merangsang. Seseorang tidak dapat mengamati ada tidaknya, tetapi gas ini bersifat racun, sehingga orang harus berhati-hati kalau ada pembakaran yang mungkin mengeluarkan karbon monoksida. ${ }^{34}$ Bahan buangan mobil dan mesin letup lainnya dapat menjadi sumber utama karbon monoksida. ${ }^{35}$

Pembakaran bahan bakar di samping terbentuk karbon dioksida, pada umumnya juga terbentuk sedikit karbon monoksida. Makin sempurna proses pembakaran, maka makin sedikit terbentuk karbon monoksi$\mathrm{da}^{36}$

Keracunan gas karbon monoksida (carbon monoxide)/gas CO (kode penyakit T, 58 ICD-10 tahun 1992) akan menyebabkan terjadinya hipoksia jaringan tubuh yang dapat membahayakan jaringan-jaringan dalam tubuh manusia. ${ }^{14,32,37,38,39}$

Dampak keracunan $\mathrm{CO}$ ini pertama kali dilaporkan oleh Bernard. ${ }^{32}$ Gas CO dihasilkan dari proses pembakaran tidak sempurna bahan organik, baik dalam alur pengolahan hasil jadi industri/occupational, ataupun proses di alam lingkungan/environmental. $^{14,37}$ Industri menyumbangkan sekitar $20 \%$ dari total gas CO yang ada, ${ }^{32}$ sedangkan dari lingkungan dapat berasal dari asap rokok (kira-kira 4\% dari total gas CO di udara),${ }^{34}$ asap knalpot mobil di jalan raya yang sibuk, dan kebakaran. ${ }^{14,34,40}$

Karbon monoksida secara praktis di produksi oleh proses-proses yang artifisial, dan $80 \%$ diduga berasal dari asap kendaraan bermotor. Konsentrasi CO di udara perkotaan menunjukkan korelasi positif dengan kepadatan lalu lintas, dan korelasi negatif dengan kecepatan angin. ${ }^{41}$

Bertambahnya gas CO pada umumnya terjadi karena proses pembakaran yang tidak sempurna, terutama dari kendaraan atau mesin bermotor. Gas ini selain memben- tuk senyawa yang stabil dengan hemoglobin darah dan menjadi karboksi-hemoglobin, juga memberi efek gangguan pada saluran pernapasan manusia. ${ }^{4}$

Gas CO dalam jumlah sedikit tidak berbahaya, bila dalam jumlah besar akan berbahaya bahkan dapat menyebabkan kematian. ${ }^{36}$ Dampak bagi kesehatan pekerja karena keracunan gas CO menyebabkan hipoksia jaringan jantung dan paru-paru. ${ }^{36}$ Pada sistem kardiovaskular maka gas CO mengikat mioglobin, sitokrom P-450 dan enzim sitokrom oksidase a3 mitokondria miokardium sehingga menyebabkan hasil oksidasi mitokondria berupa adenosin triphosphate (ATP) berkurang. ${ }^{36}$

Komplikasi pada jantung dapat berupa menurunnya kontraksi miokardium, terjadi hipotensi, aritmia ventrikuler, dan dapat menyebabkan mati mendadak (sudden death). Pada pekerja mudah terjadi penyakit koroner karena lebih cepat terjadi hipoksia, lebih sering serangan angina, terjadi peningkatan depresi gelombang ST walaupun dengan pajanan dosis rendah gas $\mathrm{CO}^{36}$

Komplikasi pada sistem saraf menyebabkan hipoksia serebral, ${ }^{32,33}$ Parkinsonisme (gejala mirip Parkinson), ${ }^{15}$ yaitu terjadi tremor, kekakuan, bradikinesia, dan cara berjalan yang tidak stabil. Teori terjadinya parkinsonisme adalah akibat terganggunya sel output, yaitu sejenis sel di dalam globus pallidus basal ganglia, terjadi hiper intensitas simetri bilateral pada globus pallidus akibat hipoksia, atau kekurangan energi pada basal ganglia, ${ }^{15,32}$ dan terjadi hipotensi sistemik. ${ }^{43}$

Komplikasi pada paru dapat berupa edema paru dan perdarahan. Edema dapat terjadi akibat terganggunya fungsi ventrikel kiri jantung atau langsung sebagai akibat hipoksia parenkim paru-paru, ${ }^{44}$ dan dapat terjadi kegagalan pernapasan. ${ }^{39}$ Gejala yang lebih ringan berupa dispneu, takhipneu dan nafas pendek. ${ }^{45}$

\section{Perubahan fungsi paru karena polusi udara}

Sistem pernapasan mengelola pertukar- 
an oksigen dan karbon monooksida antara udara dan darah. Sistem pernapasan akan melakukan dua fungsi yaitu ventilasi dan respirasi. Ventilasi mengacu pada pergerakan udara dari atmosfir masuk dan keluar paru-paru. Ventilasi berlangsung bulk flow (perpindahan atau pergerakan gas atau cairan dari tekanan tinggi ke rendah). Normal ventilasi rata-rata normal untuk dewasa yaitu 12-30 pernapasan per menit. Respirasi mengacu kepada difusi gas-gas antara alveolar dan kapiler yang memperfusinya. Respirasi berlangsung melalui difusi yaitu perpindahan suatu gas sesuai penurunan gradien konsentrasinya. ${ }^{46}$

\section{Derajat gangguan pada saluran napas di- pengaruhi oleh beberapa faktor yaitu: ${ }^{46}$}

a. Karakteristik agregat. Diameter partikel akan mempengaruhi lokasi terjadinya deposit. Partikel $>10 \mu \mathrm{m}$ akan terdeposit di saluran napas atas dan partikel $<5$ $\mu \mathrm{m}$ akan masuk ke saluran napas distal dan alveoli.

b. Sifat kelarutannya di dalam air. Gas yang mudah larut dalam air akan menimbulkan efek pada saluran napas atas, sedangkan gas yang tidak mudah larut dalam air akan menimbulkan efek di alveoli.

c. Jumlah. Gas mudah larut dalam air dalam jumlah besar dapat menimbulkan gangguan sampai ke alveoli.

Pembagian jenis kelainan fungsi paruparu hasil pengukuran spirometer terbagi atas: ${ }^{47}$

a. Normal, bila FEV1/FVC70 \% dan FVC/ VC Pred $80 \%$.

b. Kelainan tipe Obstruksi bila FEV1/ FVC $<70 \%$.

c. Kelainan tipe Restriksi bila FVC/VC Pred $<80 \%$.

d. Kelainan tipe Campuran bila FEV1/ FVC $<70 \%$ dan FVC/VC Pred $80 \%$.

Menurut tingkat berat ringan kelainan fungsi paru dibagi atas tipe obstruksi dan restriktif dikemukakan pada Tabel $3 .^{47}$
Paru-paru bekerja berat sebagai pompa mekanik yang berfungsi ganda yakni menghisap udara atmosfir ke dalam paru-paru dan mengeluarkan udara alveolar dari dalam tubuh. Hubungan fungsional antara komponen pernapasan yaitu hubungan sinergitik setiap komponen berfungsi secara sikron dan saling menunjang. ${ }^{48}$

Fungsi sistem respirasi mencakup pertukaran gas, keseimbangan asam basa, mekanisme pertahanan paru, metabolisme bahan-bahan bioaktif dan fonasi. ${ }^{49}$ Patofisiologi perubahan fungsi paru karena polusi udara dapat dikategorikan dua yaitu tipe obstruksi dan tipe restriksi. Pada tipe obstruksi terjadi gangguan pada saluran pernapasan sedangkan pada tipe restriksi terjadi penurunan pada transfer gas di dalam permukaan alveoli. ${ }^{47}$

Tabel 3. Tingkat berat ringan kelainan paru

\begin{tabular}{ccc}
\hline Tingkat & $\begin{array}{c}\text { Tipe } \\
\text { Obstruksi }\end{array}$ & $\begin{array}{c}\text { Tipe } \\
\text { Restriktif }\end{array}$ \\
\hline \multirow{2}{*}{ Ringan } & $\%$ FEV1 & $\%$ FEV1 \\
& $60-70 \%$ & $60-80 \%$ \\
Sedang & $\%$ FEV1 & $\%$ FEV1 \\
& $30-60 \%$ & $30-60 \%$ \\
\multirow{2}{*}{ Berat } & $\%$ FEV1 & $\%$ FEV1 \\
& $0-30 \%$ & $0-30 \%$ \\
\hline
\end{tabular}

Balfe et al. melaporkan tentang tingkat obstruksi dalam gangguan ventilasi restriktif terhadap 21.499 pasien yang dilakukan tes fungsi paru. Menurut Balfe et al. tingkatan obstruksi saluran pernapasan dikemukakan berdasarkan: (1) American Thoracic Society (ATS) yang berdasarkan flow expiratory volume one second (FEV1). (2) Intermbountain Thoracic Society (ITS) memprioritaskan tingkatan obstruksi berat berdasarkan ratio $\mathrm{FEV}$ 1/ FVC. ${ }^{50}$

Balfe et al. juga mendapatkan penilaian adanya gangguan obstruksi berat maka akan terjadi restriksi dengan menggunakan persentase nilai FEV1 dan penilaian tingkatan obstruksi yang berat didasarkan pada ratio FEV1 / FVC.

Pada studi kohort Balfe et al didapatkan pada tipe obstruksi ditemukan Total Lung Capacity (TLC) normal 72,2\% (1.890 pasien), mengalami peningkatan $22,2 \%$ 
(582 pasien) dan yang mengalami penurunan 5,6\% (147 pasien), dari keseluruhan pasien ini dikonfirmasi dengan pemeriksaan plethysmograph untuk mengukur volume paru-paru. Pada penelitian ini didapatkan yang mengalami obstruksi 44\% (2.619 pasien) yang kemudian akan mengalami retriksi 147 pasien. Mengikuti kriteria ATS maka yang mengalami obstruksi berat 133 pasien $(90 \%)$ sedangkan kriteria ITS hanya 4 pasien $(3 \%)$, jadi kedua metode ini signifikan berbeda $(\mathrm{p}<0,01) .^{50}$

\section{Pengukuran fungsi paru}

Pengukuran fungsi pernapasan penting bagi ahli fisiologi dan klinikus untuk mengukur seberapa banyak udara yang dapat dimasukkan selama pernapasan cepat dan dengan kecepatan maksimal. Tes fungsi pernapasan menggunakan Spirometer sebagai instrumen yang mengukur volume dan kecepatan udara selama bernapas. ${ }^{51}$

Pengukuran volume dan kapasitas paru dapat dilakukan dalam dua keadaan yaitu pengukuran statis dan pengukuran dinamis. Pengukuran statis adalah pengukuran yang dibuat tanpa memperhitungkan laju aliran udara, sedangkan pengukuran dinamis adalah pengukuran yang dilakukan dalam batasan waktu tertentu. ${ }^{52}$

Pengukuran volume dan kapasitas paru merupakan salah satu cara yang mungkin dapat digunakan sebagai cara diagnostik, tetapi hal ini secara alamiah harus diikuti dengan data sejarah penyakit seseorang pada periode waktu tertentu, serta pengukuran efek dari penanganan sebelum operasi. Adanya abnormalitas saluran pernapasan akan didapat dari angka normal FEV1 (Forced Expiratory Volume in One Second), VC (Vital Capacity), PEF (Peak Expiratory Flow) atau $\mathrm{FEV} 1 / \mathrm{VC} \%{ }^{47}$

Volume dan kapasitas paru rata-rata tergantung pada mekanika paru, dinding dada serta aktifitas otot respiratorik. ${ }^{53}$ Sebagaimana kasus pengukuran anatomi dan fisiologis lainnya, volume paru bervariasi sesuai umur, jenis kelamin, dan ukuran tubuh khususnya tinggi badan. Itulah sebabnya pengukuran volume paru rata-rata harus berdasarkan umur, jenis kelamin dan ukuran tubuh tinggi badan dan berat badan. ${ }^{49,52,54}$

Volume paru adalah pengukuran pergerakan udara selama bernapas dibagi atas empat yaitu: (1) Tidal Volume (TV) dimana laki-laki dan perempuan sama $500 \mathrm{ml}$, (2) Inspiratory Reserve Volume (IRV) dimana laki-laki $5.000 \mathrm{ml}$ sedangkan perempuan $1.900 \mathrm{ml}$, (3) Ekspiratory Reserve Volume (ERV) dimana laki-laki $1.100 \mathrm{ml}$ sedangkan perempuan $700 \mathrm{ml}$, dan (4) Residual Volume (RV) dimana laki-laki $1.200 \mathrm{ml}$ sedangkan perempuan $1.100 \mathrm{ml} .^{51}$

Kapasitas paru adalah penjumlahan dua atau lebih volume paru. Pengukuran Kapasitas paru akan dinilai dari: (1) Kapasitas vital (VC) adalah penjumlahan IRV, ERV dan VT yaitu laki-laki $4.600 \mathrm{ml}$ sedangkan perempuan $3.100 \mathrm{ml}$. Kapasitas vital akan menurun sesuai dengan bertambahnya umur. (2) Total Lung Capacity (TLC) yaitu penjumlahan kapasitas vital (VC) ditambah dengan Volume residual yaitu laki-laki $5.800 \mathrm{ml}$ sedangkan perempuan $4.200 \mathrm{ml}^{51}$

Pengukuran volume dan kapasitas paru dapat digambarkan melalui gambaran Spirogram berupa keadaan normal, obstruksi dan restriksi, dimana dihubungkan dengan Kapasitas vital paru rata-rata maksimal disebut forced vital capacity (FVC) dan Volume paru pada detik pertama disebut forced expiratory volume in $1^{\text {st }}$ second $\left(\mathrm{FEV}_{1}\right) .^{51}$

Pada tipe obstruksi maka seseorang akan mengeluhkan sesak napas (dyspnoea) disebabkan paru-paru tidak dapat memasukkan udara secara baik sehingga transfer oksigen dalam paru-paru ke dalam darah tidak memadai sehingga terjadi penurunan kapasitas paru, peningkatan Functional Residual Capacity (FRC) dan peningkatan Volume residual (Residual volume) contohnya terjadi asma, bronkitis dan empisema. Pada tipe restriksi terjadi penurunan kapasitas vital, penurunan volume residual dan Kapasitas paru total (TLC) contohnya pada karena proses fibrosis interstitial alveolar paru disebabkan asbestosis. ${ }^{55}$

Sebelum ada komputer elektronik, uji fungsi paru dilakukan dengan spirometri mekanik. Parameter inti yang di ukur dengan alat spirometer elektronik adalah deras 
aliran udara (flow). Karena waktu selama melakukan manuver dapat di ukur maka berdasarkan aliran dan waktu dapat dilakukan komputasi untuk menghasilkan volume. Selanjutnya data direkam secara digital ke dalam komputer maka berdasarkan data dapat dilukis berbagai kurva, parameter dan indeks bahkan sampai resume dan diagnosis spirometri juga dapat ditampilkan. ${ }^{56}$

\section{Dampak pencemaran udara terhadap fungsi paru}

Younes mendapatkan terjadinya penyakit paru pada pekerja yang disebabkan menghirup debu di tempat kerja, dalam penelitiannya sejak tahun 1968-1999 memberi kontribusi kematian lebih dari 120.000 kasus di Amerika Serikat, termasuk didalamnya mendekati 2.750 orang per tahun pada tahun 1999. Pada orang dewasa, 20-30\% astma disebabkan paparan debu di tempat kerja dan diperkirakan terjadinya penyakit paru obstruksi kronis 5-25\% disebabkan karena pekerjaan, serta diperkirakan biaya dari pengobatan penyakit paru obstruksi kronis sekitar lima miliar dollar. ${ }^{57}$

Mannino et al mengemukakan penyakit paru obstruksi (COPD) menyebabkan keterbatasan udara masuk sehingga udara ekspirasi menjadi lambat. Hal ini diukur dengan spirometer dimana FEV1 menurunnya secara persisten dan ratio (FEV1)/(FVC) menurun. Mengikuti klasifikasi Global Initiative for Chronic Obstructive Lung Disease (GOLD) didapatkan COPD ringan (Tingkat 1) maka FEV1/ FVC ratio < 70\% dan FEV1 diprediksi > 80\%, pada COPD sedang (Tingkat 2 dan 3) maka FEV1/FVC ratio $<70 \%$ dan FEV1 diprediksi $\leq 80 \%{ }^{58}$

Ulvestad, et al dalam laporan penelitian mereka tentang kumulatif pajanan dari debu (dust) terhadap penurunan fungsi paru pekerja di terowongan menemukan bahwa rata-rata pajanan debu pada saluran pernapasan ini sesuai analisa multiple regresi pada pekerja diatas 40 tahun ditemukan adanya penurunan FEV1 $25 \mathrm{ml}$ bagi pekerja tidak perokok, $35 \mathrm{ml}$ pekerja perokok dan 50-63 ml pada pekerja tidak perokok bekerja di terowongan. ${ }^{9}$
Samet et al. dalam penelitian mereka terhadap partikulat baik padat atau cair seperti debu (dust), partikel serbuk sari bunga (pollen) dan aerosol pada aktifitas pembakaran ditemukan bahwa ukuran partikel berhubungan signifikan dengan terkumpulnya partikel ukuran diameter $<2-3 \mu \mathrm{m}$ di bagian dalam paru-paru yaitu bronkiolus terminalis dan alveoli sedangkan partikel besar akan terkumpul di saluran napas bagian atas. Partikulat diukur dengan TSPs yaitu seluruh partikel terlarut lebih dari 30-40 $\mu \mathrm{m}$. Untuk PM10 yang dapat masuk lewat secara aerodinamik melalui inhalasi berukuran $<10$ $\mu \mathrm{m} .{ }^{11}$

Neamtu et al dalam penelitiannya tentang studi hubungan antara polusi udara dengan partikulat dan penyakit pernapasan akut di Bukares didapatkan bahwa ambien polusi udara partikulat tinggi dan meningkatkan kunjungan pasien ke rumah sakit dengan penyakit pernapasan akut lebih khusus pada orang muda. ${ }^{59}$

Bahan-bahan partikulat/debu dapat menyebabkan peningkatan kematian pada bayi prematur, selain itu mengganggu manusia khususnya menyebabkan penyakit paru seperti asma bronkial, penyakit paru obstruksi menahun (COPD), termasuk bronkitis kronis dan empisema, selain itu menyebabkan penyakit jantung. Paparan partikulat di udara yang terpolusi dapat menjadi pencetus asma berulang berupa kasus sesak napas dan batuk, serta iritasi pernapasan pada orangorang dengan saluran napas yang sensitif. ${ }^{4}$

Komponen $\mathrm{Pb}$ triakil dan diakil bila berkombinasi dengan proses fotolisis, radikal hidroksil dan ozon akan berubah menjadi bentuk $\mathrm{Pb}$ inorganik oksida. Kemampuan bertahan dari tertaetil $\mathrm{Pb}$ di udara pada musim panas kurang lebih dua jam, sedangkan trimetil $\mathrm{Pb}$ mencapai sembilan jam. Pada musim dingin kedua komponen ini dapat bertahan selama beberapa hari di udara. ${ }^{60}$

Gejala intoksikasi $\mathrm{Pb}$ tergantung pada daya tahan tubuh seseorang, kadar $\mathrm{Pb}$ dalam darah dan lama pemaparannya. Semakin lama seseorang terpapar maka gejala dan keluhannya akan makin meningkat. Umumnya gejala keracunan $\mathrm{Pb}$ terasa apabila kadar $\mathrm{Pb}$ dalam darah mencapai 40-60 
$\mu \mathrm{g} / \mathrm{dl}$ pada orang dewasa' sedangkan pada anak-anak 35-50 $\mu \mathrm{g} / \mathrm{dl} .^{61}$

Gejala intoksikasi $\mathrm{Pb}$ terbagi atas keracunan ringan, sedang, dan berat. Gejala keracunan ringan dapat berupa mialgia/ paraesthesia, kelelahan ringan, iritabilitas, dan letargi. Pada keracunan sedang dirasakan artralgia, kelelahan umum, rasa tidak enak pada perut, tidak dapat berkonsentrasi, kelelahan otot, tremor, dan sakit kepala. Keracunan $\mathrm{Pb}$ berat ditandai dengan paresis atau paralisis, encefalopati, kejang tiba-tiba, perubahan kesadaran, koma, dan kematian. $^{61}$

Hasil penelitian Sandstrom memperlihatkan bahwa pada penderita asma yang terpajan gas $\mathrm{SO}_{2}$ dengan konsentrasi $0,25-$ 0,5 ppm sudah dapat menyebabkan konstriksi saluran napas dan menyebabkan peningkatan rangsangan sensitivitas di paruparu. Rabinovitch et al. (1989), mengemukakan bahwa pada pekerja yang terpajan gas $\mathrm{SO}_{2}$ yang menderita asma akibat kerja pada pemeriksaan faal parunya akan menunjukkan penurunan volume ekspirasi paksa pada detik pertama $(\mathrm{VEP} 1=\mathrm{FEV} 1)$ dan penurunan rasio VEP1/FVC (kapasitas vital paksa paru). ${ }^{24}$

Sandstrom mengemukakan bahwa sulfur oksida $\left(\mathrm{SO}_{2}\right)$ dapat menimbulkan berbagai macam gejala seperti konjungtivitis, iritasi kulit, rhinorrhea, nyeri dada, batuk, dan sesak napas. Ia juga memaparkan bahwa bahkan pada orang sehat yang tidak hiperaktif, bila terpajan gas $\mathrm{SO}_{2}$ dengan konsentrasi di atas 5 ppm akan menimbulkan peningkatan tahanan (resistensi) saluran napas. ${ }^{24}$

American Lung Association mengemukakan bahwa gas buangan kendaraan bermotor yang menyebabkan gangguan paru adalah $\mathrm{NO}_{\mathrm{x}} \cdot{ }^{30}$ Pada suhu tinggi (panas) bila gas ini masuk ke paru-paru dapat mengiritasi dan menurunkan tahanan saluran napas terhadap infeksi seperti virus influenza. Pada udara ambien dengan konsentrasi paparan yang sering dan berlanjut akan terjadi peningkatan pula bahkan pada keadaan suhu normal, yang menyebabkan peningkatan kasus penyakit saluran napas akut pada anak-anak. ${ }^{63}$
Goings et al melaporkan efek pajanan akut dari gas $\mathrm{NO}_{2}$ dengan dosis 1-3 ppm pada 150 pemuda dewasa yang tidak merokok. Pada penelitian ini dilakukan investigasi selama dua tahun pertama antara subjek dan kontrol. Kemudian setelah diteliti ulang pada tahun ketiga ditemukan bahwa $90 \%$ daripada subjek penelitian sudah mempunyai respon antibodi terhadap paparan, dibandingkan dengan $70 \%$ kontrol yang terpapar plasebo. ${ }^{64}$

Studi dari Samet et al melaporkan bahwa kelompok orang-orang yang terpapar pada tingkat rendah dengan gas $\mathrm{CO}$ akan menyebabkan penyakit jantung iskemia, penyakit pembuluh darah perifer, dan COPD. ${ }^{11}$

Churg et al pada penelitian mereka tentang paparan kronis polusi udara dengan partikulat dosis tinggi didapatkan adanya perubahan saluran udara kecil pada penduduk di Kota Meksiko yang tidak merokok, tidak terpapar debu (dust), dan tidak menggunakan bahan bakar minyak untuk memasak. Hasil penelitian menemukan bahwa pada biopsi paru ditemukan gambaran histologis berupa fibrosis jaringan dinding paru, fibrosis otot pernapasan, dan adanya pigmen debu. ${ }^{65}$

Menurut Occupational Safety and Health Administration (OSHA) di Amerika Serikat, pekerja dapat mentoleransi pajanan gas CO hingga 100 ppm/ 8 jam/ hari. Protokol HOME, menyebutkan bila terpajan gas CO lebih dari 36 ppm / 8 jam / hari sudah harus dilakukan pemeriksaan kesehatan pada pekerja. ${ }^{40}$

\section{Upaya pembatasan pencemaran udara}

Dalam upaya pembatasan pencemaran udara, dikeluarkan berbagai peraturan/standar oleh berbagai badan dunia dan pemerintah, antara lain Center for Disease Control (CDC), American Conference of Governmental Industry Hygienist (ACGIH), Environmental Protection Agency (EPA), National Institute for Occupational Safety and Health (NIOSH), Food and Drug Administration (FDA), Consumer Product Safety Commision (CPSC), United King- 
dom (UK), dan World Health Organization (WHO).

Pemerintah Indonesia juga telah membuat peraturan perundang-undangan mengenai standar kualitas udara ambien yang harus diberlakukan di seluruh Indonesia. Peraturan perundangan yang mengatur hal tersebut adalah PP No. 41 Tahun 1999 tentang Baku Mutu Udara Ambien Nasional dapat dilihat pada Tabel $4 .^{66}$

Kristanto mengemukakan pendapat Perkins dalam bukunya Air Pollution yang telah menyusun nilai standar gas-gas atau partikel yang bisa berada dalam udara ambien dimana kehadiran kontaminan tersebut tidak berdampak negatif baik terhadap lingkungan maupun makhluk hidup. ${ }^{67}$

Laporan dari U.S. EPA, ${ }^{5}$ tentang standar kualitas udara (Tabel 5) dikemukakan dalam American Conference of Govern- mental Industrial Hygienist (ACGIH), yang kemudian dijadikan sebagai pedoman yaitu:

1. Nitrogen dioksida $\left(\mathrm{NO}_{2}\right)$ ppm: $5,6 \mathrm{mh} /$ $\mathrm{m}^{3}$. ACGIH: 3 ppm, EPA: 0,053 ppm,

2. Ozone (O3) ACGIH: kompleks termasuk waktu kerja, dan lain-lain, EPA: 0,08 ppm (8 jam) dan 0,12 ppm (1 jam),

3. Partikulat (PM 2,5) EPA: $15 \mu \mathrm{g} / \mathrm{m}^{3}$ (rata-rata) , $65 \mu \mathrm{g} / \mathrm{m}^{3}$ (24 jam),

4. Partikulat (PM 10) EPA: $50 \mu \mathrm{g} / \mathrm{m}^{3}$ (ratarata), $150 \mu \mathrm{g} / \mathrm{m}^{3}$ (24 jam),

5. Sulfur dioksida $\left(\mathrm{SO}_{2}\right)$ ACGIH: $2 \mathrm{ppm}$ (TWA) dan 5 ppm (CEILING).

6. EPA: $0,03 \mathrm{ppm}\left(80 \mathrm{mcg} / \mathrm{m}^{3}\right.$ untuk ratarata), $0,14 \mathrm{ppm}\left(365 \mathrm{mcg} / \mathrm{m}^{3}\right.$ untuk 24 jam).

7. Karbon monooksida (CO) EPA: 9 ppm (10 mg/m $\mathrm{m}^{3}$ untuk 8 jam), 35 ppm (40 $\mathrm{mcg} / \mathrm{m}^{3}$ untuk 1 jam).

Tabel 4. Baku mutu udara ambien nasional menurut PP. No. 41 Tahun 1999

\begin{tabular}{|c|c|c|c|c|}
\hline Parameter & $\begin{array}{c}\text { Waktu } \\
\text { Pengukuran }\end{array}$ & Baku Mutu & Metode Analisis & Peralatan \\
\hline $\mathrm{SO}_{2}$ & $\begin{array}{c}1 \text { Jam } \\
24 \text { Jam } \\
1 \text { Tahun }\end{array}$ & $\begin{array}{c}900 \mu \mathrm{g} / \mathrm{m}^{3} \\
365 \mu \mathrm{g} / \mathrm{m}^{3}=0,129 \mathrm{ppm} \\
60 \mu \mathrm{g} / \mathrm{m}^{3}\end{array}$ & Pararosanilin & Spektrofotometer \\
\hline $\mathrm{CO}$ & $\begin{array}{l}1 \mathrm{Jam} \\
24 \mathrm{Jam} \\
1 \text { Tahun } \\
1 \text { Jam }\end{array}$ & $\begin{array}{c}30.000 \mu \mathrm{g} / \mathrm{m}^{3} \\
10.000 \mu \mathrm{g} / \mathrm{m}^{3} \\
--- \\
400 \mathrm{ug} / \mathrm{m}^{3}\end{array}$ & NDIR & NDIR Analyzer \\
\hline $\mathrm{NO}_{2}$ & $\begin{array}{l}\text { 24 Jam } \\
1 \text { Tahun }\end{array}$ & $\begin{array}{c}150 \mu \mathrm{g} / \mathrm{m}^{3}=0,08 \mathrm{ppm} \\
100 \mu \mathrm{g} / \mathrm{m}^{3}\end{array}$ & Saltzman & Spektrofotometer \\
\hline $\mathrm{O}_{3}$ & $\begin{array}{l}1 \text { Jam } \\
1 \text { Tahun }\end{array}$ & $\begin{array}{c}235 \mu \mathrm{g} / \mathrm{m}^{3} \\
50 \mu \mathrm{g} / \mathrm{m}^{3}\end{array}$ & Chemiluminescent & Spektrofotometer \\
\hline $\begin{array}{l}\text { Hidrokarbon } \\
\text { PM - } 10\end{array}$ & $\begin{array}{l}\text { 3 Jam } \\
\text { 24 Jam }\end{array}$ & $\begin{array}{l}160 \mu \mathrm{g} / \mathrm{m}^{3} \\
150 \mu \mathrm{g} / \mathrm{m}^{3}\end{array}$ & $\begin{array}{l}\text { Flame Ionization } \\
\text { Gravimetri }\end{array}$ & $\begin{array}{c}\text { Gas Kromatografi } \\
\text { Hi-Vol }\end{array}$ \\
\hline PM 25 & $\begin{array}{l}24 \text { Jam } \\
1 \text { Tahun }\end{array}$ & $\begin{array}{l}65 \mu \mathrm{g} / \mathrm{m}^{3} \\
15 \mu \mathrm{g} / \mathrm{m}^{3}\end{array}$ & Gravimetri & $\mathrm{Hi}-\mathrm{Vol}$ \\
\hline TSP / SPM & $\begin{array}{l}24 \text { Jam } \\
1 \text { Tahun }\end{array}$ & $\begin{array}{c}230 \mu \mathrm{g} / \mathrm{m}^{3} \\
90 \mu \mathrm{g} / \mathrm{m}^{3} \\
10 \mathrm{ton} / \mathrm{Km}^{2} / \text { bulan }\end{array}$ & Gravimetri & Hi-Vol \\
\hline Debu jatuh & 30 Hari & $\begin{array}{c}\text { (Lokasi Pemukiman) } 20 \\
\text { ton/Km²/bulan (Lokasi } \\
\text { Industri) }\end{array}$ & Gravimetri & Cannister \\
\hline $\mathrm{Pb}$ & $\begin{array}{l}24 \text { Jam } \\
1 \text { Tahun }\end{array}$ & $\begin{array}{l}2 \mu \mathrm{g} / \mathrm{m}^{3} \\
1 \mu \mathrm{g} / \mathrm{m}^{3}\end{array}$ & $\begin{array}{l}\text { Gravimetri } \\
\text { Ekstraktif } \\
\text { Pengabuan }\end{array}$ & $\begin{array}{l}\text { Hi-Vol } \\
\text { AAS }\end{array}$ \\
\hline
\end{tabular}

Sumber: PP No. 41 Tahun 1999 
Tabel 5. Ambient air quality standards.

\begin{tabular}{|c|c|c|c|c|c|c|}
\hline \multirow{2}{*}{ Pollutant } & \multirow{2}{*}{$\begin{array}{c}\text { Averaging } \\
\text { Time }\end{array}$} & \multicolumn{2}{|c|}{ California Standard } & \multicolumn{3}{|c|}{ Federal Standard } \\
\hline & & Concentration & Method & Primary & Secondary & Method \\
\hline \multirow{3}{*}{$\begin{array}{l}\text { Carbon } \\
\text { monoxide } \\
(\mathrm{CO})\end{array}$} & $12 \mathrm{hr}$ & $10 \mathrm{ppm}$ & \multirow{3}{*}{$\begin{array}{l}\text { Nondispersive } \\
\text { infrared } \\
\text { spectroscopy }\end{array}$} & -- & \multirow{3}{*}{$\begin{array}{l}\text { Same as } \\
\text { Primary } \\
\text { standard }\end{array}$} & \multirow{3}{*}{$\begin{array}{l}\text { Nondispersive } \\
\text { infrared } \\
\text { spectroscopy }\end{array}$} \\
\hline & $8 \mathrm{hr}$ & -- & & $10 \mathrm{mg} / \mathrm{m}^{3}$ & & \\
\hline & $1 \mathrm{hr}$ & $40 \mathrm{ppm}$ & & $40 \mathrm{ppm}$ & & \\
\hline \multirow{3}{*}{$\begin{array}{c}\text { Nitrogen } \\
\text { dioxide }\left(\mathrm{NO}_{2}\right)\end{array}$} & Annual & & \multirow{3}{*}{$\begin{array}{l}\text { Saltzman } \\
\text { Method }\end{array}$} & $100 \mu \mathrm{g} / \mathrm{m}^{3}$ & \multirow{3}{*}{$\begin{array}{l}\text { Same as } \\
\text { Primary } \\
\text { standard }\end{array}$} & \multirow{3}{*}{$\begin{array}{c}\text { Colorimetric } \\
\text { method using } \\
\mathrm{NaOH}\end{array}$} \\
\hline & average & - & & $(0,05 \mathrm{ppm})$ & & \\
\hline & $1 \mathrm{hr}$ & $0,25 \mathrm{ppm}$ & & --- & & \\
\hline \multirow{4}{*}{$\begin{array}{l}\text { Sulfur dioxide } \\
\qquad\left(\mathrm{SO}_{2}\right)\end{array}$} & Annual & -- & \multirow{4}{*}{$\begin{array}{l}\text { Conductimetri } \\
\text { method }\end{array}$} & $80 \mu \mathrm{g} / \mathrm{m}^{3}$ & $60 \mu \mathrm{g} / \mathrm{m}^{3}$ & \multirow{4}{*}{$\begin{array}{l}\text { Pararosaline } \\
\text { method }\end{array}$} \\
\hline & $24 \mathrm{hr}$ & $\begin{array}{c}0,04 \mathrm{ppm} \\
\left(105 \mu \mathrm{g} / \mathrm{m}^{3}\right)\end{array}$ & & $\begin{array}{c}(0,03 \mathrm{ppm}) \\
365 \mu \mathrm{g} / \mathrm{m}^{3} \\
(0,145 \mathrm{ppm})\end{array}$ & $\begin{array}{c}(0,02 \mathrm{ppm}) \\
260 \mu \mathrm{g} / \mathrm{m}^{3} \\
0,10 \mathrm{ppm}\end{array}$ & \\
\hline & $3 \mathrm{hr}$ & -- & & -- & $1300 \mu \mathrm{g} / \mathrm{m}^{3}$ & \\
\hline & $1 \mathrm{hr}$ & $0,5 \mathrm{ppm}$ & & -- & $\begin{aligned} 0,3 \mathrm{pp} \\
--\end{aligned}$ & \\
\hline \multirow[t]{2}{*}{$\begin{array}{l}\text { Suspended } \\
\text { particulate } \\
\text { matter (SPM) }\end{array}$} & $\begin{array}{l}\text { Annual } \\
\text { Geometric } \\
\text { mean }\end{array}$ & $60 \mu \mathrm{g} / \mathrm{m}^{3}$ & \multirow[t]{2}{*}{$\begin{array}{l}\text { High Volume } \\
\text { sampling }\end{array}$} & $75 \mu \mathrm{g} / \mathrm{m}^{3}$ & $60 \mu \mathrm{g} / \mathrm{m}^{3}$ & \multirow[t]{2}{*}{$\begin{array}{l}\text { High Volume } \\
\text { sampling }\end{array}$} \\
\hline & $24 \mathrm{hr}$ & $100 \mu \mathrm{g} / \mathrm{m}^{3}$ & & $260 \mu \mathrm{g} / \mathrm{m}^{3}$ & $150 \mu \mathrm{g} / \mathrm{m}^{3}$ & \\
\hline $\begin{array}{c}\text { Lead } \\
\text { (Particulate) }\end{array}$ & $\begin{array}{l}\text { 30-day } \\
\text { average }\end{array}$ & $1,5 \mu \mathrm{g} / \mathrm{m}^{3}$ & $\begin{array}{l}\text { High Volume } \\
\text { sampling } \\
\text { Diltiazone }\end{array}$ & -- & -- & -- \\
\hline $\begin{array}{l}\text { Hidrogen } \\
\text { sulfide }\end{array}$ & $1 \mathrm{hr}$ & $\begin{array}{c}0,03 \mathrm{ppm} \\
\left(42 \mu \mathrm{g} / \mathrm{m}^{3}\right)\end{array}$ & $\begin{array}{l}\text { Cadmium } \\
\text { hydroxide St } \\
\text { Ractan }\end{array}$ & -- & -- & -- \\
\hline Hidrocarbon & $3 \mathrm{hr}$ & -- & -- & $\begin{array}{l}160 \mu \mathrm{g} / \mathrm{m}^{3} \\
(0,24 \mathrm{ppm})\end{array}$ & $\begin{array}{l}\text { Same as } \\
\text { Primary } \\
\text { standard }\end{array}$ & $\begin{array}{c}\text { Flame } \\
\text { ionization } \\
\text { detection }\end{array}$ \\
\hline $\begin{array}{l}\text { Photochemical } \\
\text { oxidants }\end{array}$ & $1 \mathrm{hr}$ & $\begin{array}{r}0,10 \mathrm{ppm} \\
\left(200 \mu \mathrm{g} / \mathrm{m}^{3}\right)\end{array}$ & $\begin{array}{l}\text { Neutral } \\
\text { buffered KI }\end{array}$ & $\begin{array}{l}160 \mu \mathrm{g} / \mathrm{m}^{3} \\
161 \mu \mathrm{g} / \mathrm{m}^{3}\end{array}$ & $\begin{array}{l}\text { Same as } \\
\text { Primary } \\
\text { standard }\end{array}$ & $\begin{array}{l}\text { Chemilumines } \\
\text { cent method }\end{array}$ \\
\hline
\end{tabular}

Sumber: Ryadi, 1982

\section{Standar pengukuran volume dan kapa- sitas paru dengan spirometer}

1. $\mathrm{FEV}_{1}$ adalah volume udara yang dapat diekspirasi secara teratur sampai maksimal. Setelah suatu inspirasi yang sedalam-dalamnya, dimana pada orang dewasa normal $80 \%$ atau dibawah 1.000 cc, Rumus $\mathrm{FEV}=\mathrm{IRV}+\mathrm{TV}+\mathrm{ERV}$ $(100 \%)$. Biasanya dihitung besarnya FEV sesudah waktu 1 detik, disingkat $\mathrm{FEV}_{1}$.

Jika $\mathrm{FEV}_{1}$ kurang dari $70 \%$ maka ada obstruksi jalan napas. $\mathrm{FEV}_{1}$ adalah sebagian dari FVC yang didapatkan selama satu detik yang pertama
2. $\mathrm{FEV}_{1} \%$ adalah volume udara yang dike-luarkan dalam satu detik dikali 100 kapasitas vital.

3. FVC adalah Kapasitas Vital Paksa paru-paru yaitu sejumlah udara yang dida-patkan dengan cara menghembuskan udara ke dalam spirometer maksimal dan secepatcepatnya setelah sebelum-nya menghirup udara secara maksimal.

Rumus $\quad \mathrm{FVC}=\mathrm{RV}+\mathrm{ERV}+\mathrm{k} .1 \quad 2.200$ / $1.800 \mathrm{ml}$.

4. $\mathrm{FEV}_{3}$ (Forced Expiration Volume third second) adalah volume udara ekspirasi secara teratur sampai maksimal. Setelah suatu inspirasi yang 
sedalam-dalamnya, dimana pada orang dewasa normal 97\%. Rumus $\mathrm{FEV}=\mathrm{IRV}+\mathrm{TV}+\mathrm{ERV}(100 \%) \mathrm{Bi}-$ asanya di hitung besarnya FEV sesudah waktu 3 detik, disingkat FEV3. Jika FEV3 kurang dari 97\% maka ada obstruksi jalan napas pada ekspirasi detik ketiga.

5. Kapasitas Vital (VC) adalah penjumlahan IRV, ERV dan VT yaitu laki-laki $4.600 \mathrm{ml}$ sedangkan perempuan $3.100 \mathrm{ml}$. Menilai kapasitas paru melalui Total Lung Capacity (TLC) yaitu penjumlahan kapasitas vital (VC) ditambah dengan volume residual dimana pada laki-laki 5.800 ml sedangkan perempuan $4.200 \mathrm{ml}$.

6. VC pred (Vital Capacity predicted) adalah Kapasitas vital yang diperkirakan. Kapasitas vital yang seharusnya pada orang dewasa dengan umur dan tinggi badan tertentu serta dalam keadaan sehat. VC predicted adalah volume gas yang tertinggal dalam paru pada akhir ekspirasi tidal normal. VC prediksi menggunakan formula Baldwin yaitu:

Laki-laki: KV=(27,63-0,112 . U) x TB (satuannya $\mathrm{ml}$ ).

Perempuan : KV=(21,78 - 0,101

.U) $\mathrm{x}$ TB (satuannya ml).

$\mathrm{KV}=\mathrm{VC}=$ Kapasitas Vital. $\mathrm{U}=\mathrm{Umur}$ dalam tahun. $\mathrm{TB}=$ Tinggi badan dalam $\mathrm{cm}$.

7. VC\% (Prosentase Vital Capacity) adalah persentase volume gas dalam paru setelah ekspirasi maksimal

(Sumber : Levitsky, 2000).

\section{KESIMPULAN}

Semakin bertambahnya jumlah kendaraan bermotor mengakibatkan polusi udara makin bertambah dan berkembang menjadi masalah global, yang menimbulkan dampak negatif antara lain masalah kesehatan.

Penyakit paru merupakan salah satu masalah kesehatan utama di Indonesia yaitu sekitar $30-40 \%$ penyakit dan penyebab kematian adalah penyakit paru dengan berbagai bentuknya. Hasil SKRT ditemukan terjadi trend peningkatan gejala batuk dalam satu bulan akibat polusi udara meningkat dari $16,8 \%$ menjadi $22,5 \%$ dan kematian akibat infeksi saluran napas juga meningkat dari $6,2 \%$ pada tahun 1986 menjadi 9,2\% pada tahun 1992.

Mobilitas manusia semakin beragam sehingga dukungan sistem transportasi makin baik. Sistem transportasi yang tidak bersahabat dengan lingkungan akan memberikan dampak langsung maupun tidak langsung bagi kehidupan manusia seperti dampak terhadap lingkungan, kesehatan maupun sosial ekonomi. Oleh karena itu untuk menghindari semakin menurunnya kualitas lingkungan maka sistem transportasi ini perlu dikembangkan menjadi sistem transportasi yang berkelanjutan.

Diharapkan dengan mengetahui batasan pencemaran udara, jenis dan dampak partikel debu dan gas kendaraan bermotor dan dampaknya bagi kesehatan membuat kita harus lebih memberikan perhatian terhadap lingkugan hidup sekitar perkotaan. Peranan kerjasama lintas sektoral untuk mengatasi polusi partikel debu dan gas buangan perlu ditingkatkan dan pengaturan kendaraan layak beroperasi akan menekan munculnya kasus infeksi saluran napas dan gangguan pernapasan.

\section{DAFTAR PUSTAKA}

1. Munthe E, Yunus F, Wiyono WH, Ikhsan M. Pengaruh inhalasi sulfur oksida terhadap kesehatan paru. Cermin Dunia Kedokteran. 2003;138:29-33.

2. Aditama YT. Paru kita masalah kita. Medika. November 2002;11.

3. Mangunegoro H, Sutoyo DK. Environmental and occupational lung diseases in Indonesia. Respirology. 1996;I:8591.

4. American Lung Association. Outdoor air pollution. [homepage on the Internet]. 2003. [diambil 23 Mei 2003]. Available from: http://www.who.int/outdoorairpollution.

5. Pirngadie BH. Strategi penanggulangan polusi udara dari sektor transportasi. Simposium ke 4 FS-TPT Udayana Bali, 8 November 2001. 
6. Menteri Negara Kependudukan dan Lingkungan Hidup Republik Indonesia. Agenda 21 Indonesia. Jakarta 1997.

7. Warouw F. Analisis hubungan kadar $\mathrm{Pb}$ dalam darah dengan lama kerja pedagang kaki lima di pusat kota Manado akibat pemaparan gas buangan kendaraan bermotor yang mengandung $\mathrm{Pb}$. [PhD Tesis]. Manado: Pascasarjana Unsrat;2003.

8. Marcelo B, Paulo HN, Saldiva. Respiratory changes due long-term exposure to urban level of air pollution. J. Chest. 1998; 113: 1312-8.

9. Ulvestad B, Bakke B, Eduard W, Kongerud $J$, and Lund MB. Cumulative exposure to dust causes accelerated decline in lung function in tunnel workers. Occupational Environment Med. [serial online]. 2001 [diambil April 2003]; 58: 663-669. Available at: http://www.occenvmed.com.

10. Peters A, Dockery DW, Muller JE. Increased particulate air pollution and the triggering of myocardial infarction. Department of Environment Health. [homepage on the Internet]. 2001 [diambil Januari 2004]. Available at : http://www.circulationsha.org.

11. Samet JM, Dominici F, Curriero FC. Fine particulate air pollution and mortality in 20 U.S. Cities, 1987-1994. The New England Journal of Medicine. 2000 Dec 14; 343(24)

12. Amsyari F. Prinsip-prinsip masalah pencemaran Lingkungan. Jakarta: Ghalia Indonesia, 1986.

13. Harsanto JBB. 2001. Polusi udara, pengaruh, serta cara penanggulangannya. Seminar Nasional Lingkungan Hidup: Strategi Kebijakan Pengendalian Polusi Udara dalam Menuju Program Langit Biru. Yogyakarta, 9 Mei 2001.

14. Kindwall EP. Carbon monoxide. The Chemical Occupational Environment. In: Zenz Carl, Dickerson OB, Hovart EP, Editors. Occupational Medicine. $3^{\text {th }}$ ed. St. Louis: Mosby Year Book Inc, 1994; p. 447-52.

15. Fine LJ, Rosenstock L. Cardiovascular disorders, evaluation and treatment. In: Rosenstock L, Cullen MR. Editors. Textbook of Clinical and Environmental Medicine. Philadelphia: WB Saunders Co, 1994; p. 389-93.
16. United States Environment Protection Agency (US EPA). National Air Quality and Emissions Trends Report.. U.S. EPA. Office of Air Quality Planning and Standards. Washington, DC; 1998.

17. WHO. Particulate matter (PM), Total suspended particulate (TSP), PM 10 and PM 2,5. WHO, Int. [homepage on the Internet]. 1986 [diambil 24 Mei 2003]. Available at: http://www.who.int/environmentalinformation/air/guideline/cha pter3.htm.

18. Bruce N, Padilla RP, Albalak R. Protection of Human Environment. WHO. [homepage on the Internet]. 2002 [diambil 23 Maret 2003]. Available at: http//www.who.int.gov.

19. Committee on the Medical effects of air pollutants (COMEAP), Statement on banding of air quality, Air Quality Standards. Department of Health, U.K. [homepage on the Internet] 2003 [diambil 23 Maret 2003]. Available at: http: //www.departmentofheal thairquality. com.

20. Environment Protection Agency (EPA). Public Health Statement for Lead, August. U.S. Department of Health and Human Services. [homepage on the Internet]. 1997 [diambil 23 Mei 2003]. Available at: http://www.atsdr. cdc.gov.

21. Sumber daya udara di Jakarta, NKLD Buku II DKI Jakarta. [homepage on the Internet]. 2000 [diambil 23 Mei 2003]. Di dapat dari: http://www.polusiudara. com.

22. Lannefors $\mathbf{H}$, Hansson HC, Granat $\mathbf{L}$. Background aerosol composition in southern Sweden - Fourteen micro and macro constituents measured in seven particle size intervals at one site during year. Atmos Environ. 1983;17:87-101.

23. Chamberlain A, Heard C, Little MJ, Micciolo R, Andrea FD. The disperseon of lead from motor exhausts. Philos Trans R Soc Lond A. 1979;290:557-89.

24. Sandstrom T. Respiratory effect of air pollution: experimental studies in humans. Eur Respir J. 1995;8: 986-9.

25. Lazarus CS, Wong HH, Watts JM, Boushey HA, Lavins BJ, Minkwitz MC. The leukotriene receptor antagonist zafirlukast inhibits sulfur dioxideinduced bronchoconstriction in patients with asthma. Am.J. Respir Crit Care 
Med. 1997;156:1725-30.

26. Balmes RJ. Tager I. Air pollution. In: Murray JF, Nadel JA, eds. Textbook of respiratory medicine. $3^{\text {rd }}$ ed. Philadelphia: WB Saunders Co, 2000; p. 1885-93.

27. Malachowski MJ. Health effects of toxic substances, Inhalation $\mathrm{SO}_{2}$. WSU. [homepage on the Internet]. 1995 [diambil 23 Maret 2003]. Available at: http: www/cc.wsu.edu/research/wesberg_HT $\mathrm{ML} / \mathrm{SO}_{2}$ module/healtheffects. htm.

28. Samet JM, Dominici F, Curriero FC. Fine particulate air pollution and mortality in 20 U.S. Cities, 1987-1994. The New England Journal of Medicine. Dec 14 2000; no. 24, Vol. 343.

29. Waldbott GL. The Sulfur oxide. In: Waldbott GL, ed. Health effects on Environmental Pollutants. $2^{\text {nd }}$ ed. St Louis: CV Mosby Co., 1978; p. 85-101.

30. American Lung Association. Diesel Fumes and American Manufacturers. Spark Technology, Inc. [homepage on the Internet]. 2003 [diambil 23 Mei 2003]. Available at: http://www.Thefilterforumissuetrends. html.

31. Soejachmaoen M, Rahman A, Meiviana A. Kualitas udara semakin memburuk, perangkat hukum mengenai pencemaran udara harus segera dibuat. Jakarta: Pelangi. [homepage on the Internet]. 8 Oktober 2002 [diambil April 2003]. Di dapat dari: http//www. Pelangipressrelease. htm.

32. Chale SN. Carbon monoxide poisoning, environmental toxins. In: Viccelio P, editors. Handbook of Medical Toxicology, $1^{\text {st }}$ ed, Boston: Little, Brown and Co, 1993; p. 639-46.

33. Benowitz NL. Cardiovascular toxicology. Occupational Illness. In: La Dou J. Editor. Occupational and Environmental Medicine. International $2^{\text {nd }}$ ed. Stamford: a Lange Medical Book, 1997; p. 328-32.

34. Bleecker ML. Clinical presentation of selected neurotoxic coumponds. In: Bleecker ML, Harsen JA, editors. Occupational Neurology and Clinical. Neurotoxicology. Baltimore: William \& Wilkins, 1994; 211: 207-08.

35. Ryadi, S. Polusi udara. Surabaya, Indonesia: Usaha Nasional, 1982; p. 5059.
36. Prawiro RH. Ekologi lingkungan pencemaran, Semarang, Indonesia, 1983; p. 35-65.

37. School of Medicine. Carbon Monoxide Headquarter. Wayne State University, 1999.

38. Jones AL, Volans G. Carbon monoxide poisoning. Recent advances management of self poisoning. Br Med J. 1999; 319: 1414-17.

39. Kales SN. Carbon Monoxide intoxication. Am. Fam Physician. 1993;48:1100-04.

40. Wichaksana A, Astono S, Hanum K. Dampak keracunan gas karbon monoksida bagi kesehatan pekerja. Cermin Dunia Kedokteran. 2002;136:2429.

41. Slamet JS. Kesehatan lingkungan. Jakarta: Gajah Mada University Press, 2000.

42. Rondonuwu EE. Pengaruh polusi gas kendaraan bermotor karbon monooksida terhadap kadar karboksihemoglobin pedagang kaki lima di pusat kota Manado [Tesis]. Manado: Pascasarjana Unsrat, 2003.

43. Mancall EL. General editor. Continuum life long learning in neurology. Neurotoxicology Part A. 1999; 5(2): 91-3.

44. Di Maio DJ. Carbon monoxide poisoning. In: Forensic Pathology. Di Maio VJ. Editors. Boca Raton: CRC Press, 1993; p. 347-54.

45. Lu FC. Efek toksik, prinsip umum toksikologi. Dalam: Toksikologi Dasar, Asas, Organ Sasaran dan Penilaian Risiko. Editor. Edisi kedua. Jakarta: UI-Press, 1995; p. 48-51.

46. Corwin EJ. Sistem pernapasan. Buku Saku Patofisiologi (Handbook of Pathophysiology). Lippincott-Raven Publishers, Inc. Alih bahasa: B.U. Pendit. Jakarta: EGC, 2000; Bab 12, 395-441.

47. Guyton AC, Hall J.E. Respiration. In: Textbook of Medical Physiology. $9^{\text {th }}$ ed. Philadelphia: WB Saunders Co, 1994.

48. Levitsky GM. Physiology of respiratory alveolar ventilation. [homepage on the internet] 2000. [diambil Januari 2004]. Didapat dari URL: http://www. mednets.com.

49. Spirometry: Interpretation of ventilatory function test. [homepage on the internet] 2004. [dikunjungi Januari 2004]. Available at: http://www.nationalasth- 
ma.org.au/publication/ spiro/ivft.html.

50. Balfe DL, Lewis $\mathbf{M}$, Mohsenifar $\mathbf{Z}$. Grading the severity of obstruction in the present of a restrictive ventilatory defect. American College of Chest Physicians. Chest. [serial online]. 2002 [dikunjungi 14 April 2004]; 122: 13651369. Available at: http://www. Chestonline.com.

51. Silverthorn DU, Ober WC, Garrison CW, Silverthorn AC. Respiratory physiology. Human Physiology an Integrated Approach. Prentice Hall Inc, 2001; p. 496-541.

52. Maskrey M. Assessment of pulmonary function. Pulmonary Lecture, 5 hal. [homepage on the internet]. 2000 [dikunjungi 23 Maret 2003]. Didapat dari URL : http://www.maskreyheartandlung.com

53. Jhonson AT. Biomechanics and exercise physiology. New York: J Wiley\& Sons, 1991.

54. Mc Ardle WD. Exercise physiology: energy nutrition and human performance. Third edition, Philadephia: Lea and Febriger, 1991.

55. Waldron HA. Occupational health practice. Butterworths. [homepage on the internet] 1998. [dikunjungi April 2003]; p. 221 - 224. Available at: http:// www.managementofdusthazardsanddis eases.Introductiontooccupationallungdi sease.

56. Sumayku JN. Pengaruh paparan debu kayu terhadap faal paru pekerja pem-buat perabot/mebel kayu di kota Bitung. [Tesis]. Manado: Pascasarjana Unsrat, 2004.

57. Younes M. Air quality guideline, WHO. [homepage on the internet] 1999. [dikunjungi April 2003]. Available at: http://www.who.int/airpollutionguidelin ewho.

58. Mannino DM, Homa DM, Akinbami LJ. Chronic obstructive pulmonary disease surveillance-United States 1971-2000. CDC. [homepage on the internet] 2002. [dikunjungi 23 Maret 2003]. Available at: http://www.cdc. gov. or email: mmwrq@cdc.gov.

59. Neamtu A, Niciu E, Oranici V. Studies on the relation between air pollution with suspended particulate matter and acute respiratory diseases admissions. Bucharest. [homepage on the internet] 2003. [dikunjungi 23 Maret 2003]. Available at: http://www.studiesonthelationbetweenair.or.au.

60. DeJonghe WRA, Adams FC. Biogeochemical cycling of organic lead compounds. Adv Environ Sci Technol. 1986; 17: 561-94.

61. Case studies in environmental medicine lead toxicity, ATSDR. [homepage on the internet] 1995. [dikunjungi 23 Maret 2003]. Available at: http:// www.atsdr.cdc.gov/HEC/HSPH/caselea d.html.

62. Rabinovitch S, Greyson ND, Weiser W. Clinical and laboratory features of acute sulfurdioxide inhalation poisoning: Two-year Follow up. Am Rev Respir Dis. 1989; 139: 556-8.

63. Spirometry. Interpretation of ventilatory function test. [homepage on the internet] 2003b. Available at: http://www. nationalasthma.org.au/publication/spiro /ivft.html

64. Goings SA, Kulle TJ, Bascom R. Effect of nitrogen dioxide exposure on susceptibility to Influenza a virus infection in healthy adults. Am Rev Respir Dis. 1989; 139: 1075-1081.

65. Churg A, Brauer M, Avila-Casado MC, Fortoul TI, Wright JL. Chronic exposure to high levels of particulate air pollution and small airway remodeling. Environment Health Perspective. [serial online] 2003. [dikunjungi 14 April 2004]; 111: 714-718. Available at: http://www.ehponline.com.

66. Peraturan Pemerintah No. 41 Tahun 1999, Baku Mutu Udara Nasional. Jakarta, 1999.

67. Kristanto P. Polusi lingkungan. Dalam: Ekologi Industri. Surabaya: ANDI Yogyakarta dan LPPM Univ. Kristen PETRA, 2002; p. 96-139. 